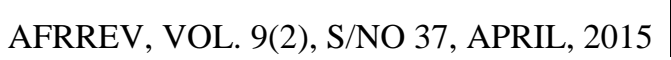 \\ African Research Review
}

An International Multidisciplinary Journal, Ethiopia

Vol. 9(2), Serial No. 37, April, 2015: 104-117

ISSN 1994-9057 (Print) ISSN 2070-0083 (Online)

DOI: http://dx.doi.org/10.4314/afrrev.v9i2.8

\section{Corporate Governance in the Nigerian Banking Industry: Issues and Challenges}

\author{
Garuba, Anthony $O$. \\ Department of Accounting and Finance, \\ College of Social and Management Sciences, \\ Western Delta University, Oghara \\ Delta State, Nigeria \\ E-mail: anthonygaruba@yahoo.com \\ $\&$ \\ Otomewo, Gene Oghenenohwo T. \\ Department of Management Sciences, \\ College of Social and Management Sciences, \\ Western Delta University, Oghara \\ Delta State, Nigeria \\ E-mail: oghenenohwo@yahoo.com
}

\begin{abstract}
Globalization no doubt has made the world a global village. This has given rise to the continuous integration of the world economy and capital markets which has in turn given rise to increase in the interdependence of international financial markets. It has also given rise to increased mobility of capital across the globe. Therefore, one way to assure investors across the globe that their investments are safe is by putting in
\end{abstract}

Copyright (C) IAARR, 2015: www.afrrevjo.net

Indexed African Journals Online: www.ajol.info 
place good corporate governance. That is, ensuring that business operations are carried out transparently and internal controls are adhered to. The corporate scandals experienced at the turn of this century across the globe and the recent bank crisis in Nigeria are traceable to poor corporate governance. This study is aimed at examining the corporate governance of the Nigerian banking industry and how to address the challenges posed by poor corporate governance in order to instill public confidence in corporate reporting. The paper adopted a conceptual approach. The finding reveals that the bank crisis is traceable to poor corporate governance practices and laxity in credit administration processes. It is therefore, recommended amongst others that there should be zero tolerance for corporate governance infraction and shareholders should be alive to their responsibilities by being active at the Annual General Meeting (AGM).

\section{Introduction}

Globalization and Information and Communication Technology (ICT) took the world by storm and have reduced the world to a global village. This has given rise to the continuous integration of the world economy and capital markets which has in turn given rise to increase in the interdependence of international financial markets. As a result of this, there is increased mobility of capital across boundaries of the globe. Therefore, in order to ensure and sustain investors' confidence in the capital market, the issue of corporate governance has now been brought to the front burner because that is the only way corporate financial reporting can be seen to be transparent (Garuba \&Donwa, 2011).

Corporate governance could be thought of as the combined statutory and nonstatutory framework within which boards of directors exercise their fiduciary duties to the organizations that appoint them. The key issue is that 'directors owe to shareholders, or perhaps to the corporation, two basic fiduciary duties: the duty of loyalty and the duty of care'. The primary goal of corporate governance is to enhance the value of a company through ethical behavior, espousing a policy of openness and fairness and ensuring informed decision making throughout the company. Unfortunately, the center of corporate ethics - the board of directors - in certain cases became a magnet for unethical practices. Blinded by the glare of a rapidly growing stock market, pressured by stockholders for ever-increasing returns, and led by executives seeking to maximize bonuses based on stock performance, certain boards of directors and audit committees failed to constrain "creative" accounting to keep up their earnings numbers. It must have seemed to some directors that the investing public really did not care about issues such as executive compensation, as long as they made their double-digit returns.

Poor corporate governance has been the root cause of most corporate failures worldwide. Recent examples of massive corporate collapse resulting from weak 
systems of corporate governance have highlighted the need to improve and reform corporate governance at both the domestic and international levels. In the wake of Enron and other similar cases, countries around the world have reacted quickly by pre-empting similar events domestically. As a speedy response to these corporate failures, the United States of America (USA) issued the Sarbanes-Oxley Act in July 2002, whereas in January 2003 the Higgs Report and the Smith Report were published in the United Kingdom (UK), again in response to their corporate governance failures. Nigeria's Securities and Exchange Commission (SEC) in 2003 released the Code of Best Practices for Public Companies in Nigeria. The Central Bank of Nigeria (CBN) also issued the Code of Corporate Governance for banks in Nigeria Post Consolidation (which became effective on April 3, 2006) to deal with issues of transparency, equity ownership, criteria for the appointment of directors, board structure and composition, accounting and auditing, risk management and financial reporting.

The quest for good corporate governance has become the dominant theme in global economic issues. The reason is not far-fetched because most of the adverse consequences wrought by the global financial crisis are direct fallouts of sloppy corporate governance regimes.

Therefore, the objective of this paper is to examine the corporate governance in the Nigerian banking industry and how to address the challenges posed by poor corporate governance in order to instill public confidence in corporate reporting of the banking industry. The paper is structured into five parts as follows: Meaning and definition of corporate governance, theories of corporate governance, corporate governance in the Nigerian banking industry, issues and challenges; and conclusion/recommendations.

\section{Meaning and Definition of Corporate Governance}

The Sir Adrian Cadbury Report on the Financial Aspects of corporate governance (1992) defined corporate governance as "The system by which companies are directed and controlled". According to Owojori (2010), corporate governance is the system of internal controls and procedures by which individual companies are managed. It provides a framework that defines the rights, roles and responsibilities of different groups - the management, board, controlling shareowners and minority or non-controlling shareowners within an organization. Dayton (1984) states that corporate governance includes the processes, structures and relationships through which the board of directors oversees what the executives do. While Shleifer and Vishny (1997) define corporate governance as the ways in which suppliers of finance to corporations assure themselves of getting a return on their investment. Zingales (1998), views governance systems as the complex set of constraints that shape the ex post bargaining over the quasi-rents generated by the firm. Taking a broad 
perspective Gillan and Starks (1998) define corporate governance as the system of laws, rules, and factors operations at a company. From the foregoing, it shows that the definition of corporate governance differs depending on one's view of the word. Irrespective of the particular definition used, researchers often view corporate governance mechanisms as falling into one of two groups: those internal to firms and those external to firms.

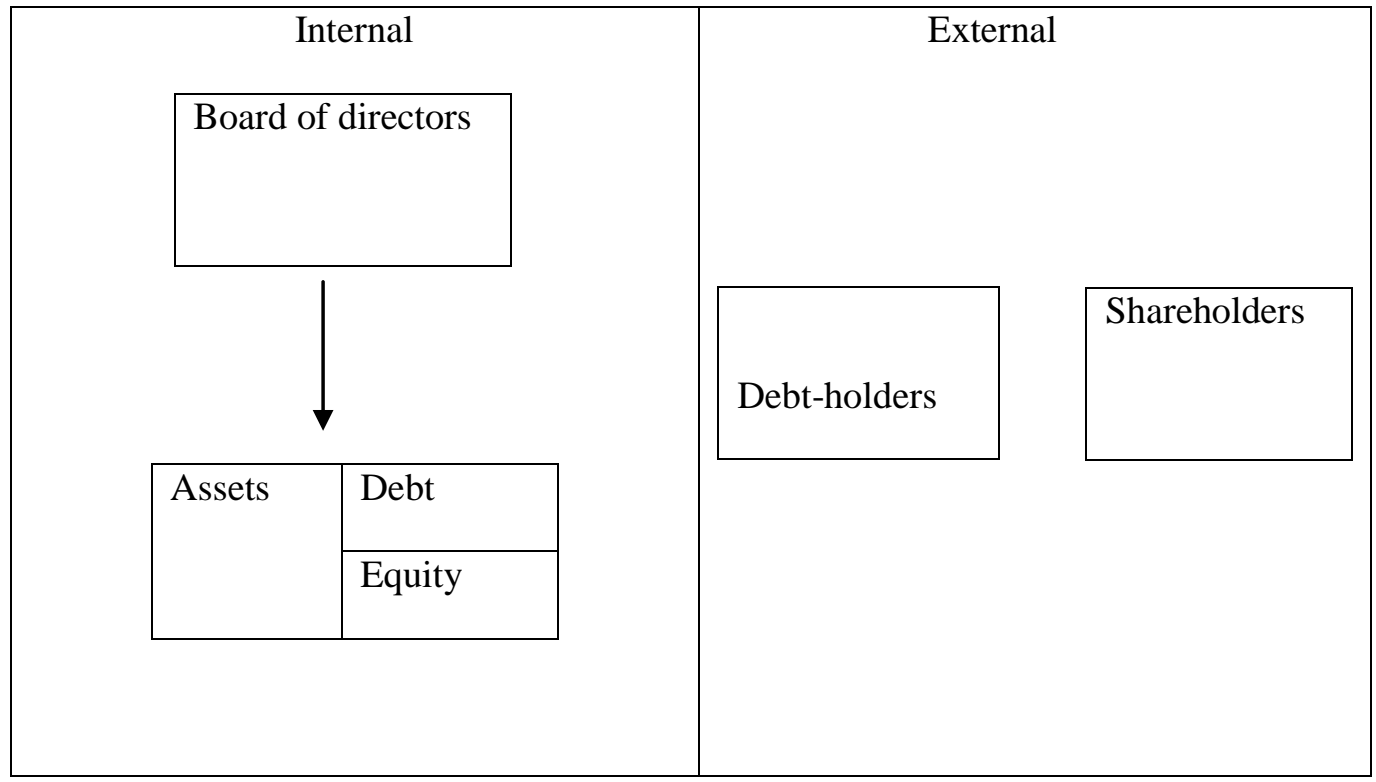

Fig. 1 Corporate Governance: Beyond the financial position Model

Fig. 1 above depicts a simple financial position model of the form of the firm and captures the essence of the relationship between internal and external factors. The left hand side of the diagram comprises the basics of internal control. Management, as agents of the shareholders, decides in which assets to invest, and how to finance those investments. According to Jensen (1993), the Board of Directors at the apex of internal control systems is charged with advising and monitoring management and has the responsibility to hire, fire, and compensate the senior management team. The right hand side of the diagram introduces elements of external governance arising from the firm's need to raise capital. With globalization a firm raises capital from any part of the world. Further, it highlights that in the publicly traded firm, a separation exists between capital providers and those who manage the capital. This separation creates the demand for corporate governance structures. As Shleifer and Vishny (1997) put it, the suppliers of finance use corporate governance to ensure that 
they will get a return on their investment. The diagram also captures the link between shareholders and the board of directors. Shareholders, the residual claimants elect board members and boards, as established in the law (Companies and Allied Matters Act), owe a fiduciary obligation to shareholders. Of course, firms are more than just boards, managers, shareholders and debt-holders.

In general, good corporate governance practices according to Owojori (2010), seek to ensure that:

(i) Board Members act in the best interests of Shareholders;

(ii) The Company acts in a lawful and ethical manner in their dealings with all stakeholders and their representatives;

(iii) All Shareholders have the same right to participate in the governance of the Company. These include a set of rights including secure ownership of shares, right to full disclosure of information, voting rights, participation in decisions on sale or modification of corporate assets including mergers and new share issues, and the right to receive fair treatment from the Board and management. The equitable treatment of shareholders protects the minority shareholders rights by setting up systems that keep insiders, including managers and directors, from taking advantage of their roles. All rights of Shareholders and other stakeholders should be clearly delineated and communicated;

(iv) The Board and its committees are structured to act independently from management, individuals or entities that have control over management, and other non-Shareholder groups;

(v) Appropriate controls and procedures are in place covering management's activities in running the day-to-day operations of the Company; and

(vi) The Company's operating and financial activities, as well as its governance activities, are consistently reported to Shareholders in a fair, accurate, timely, reliable, relevant, complete and verifiable manner.

How well a Company achieves these goals depends, in large part, on the adequacy of the Company's corporate governance structure and the strength of the Shareholder's voice in corporate governance matters, through Shareholder voting rights. The success of the Board in safeguarding Shareholder interests depends on these factors enumerated above.

\section{Theories of Corporate Governance}

Akintoye (2010) states that there are, essentially, three theories of corporate governance: the steward-ship theory, the agency theory and the market theory. 
The stewardship theory of corporate governance holds that, because people can be trusted to act in the public good in general and in the interests of their shareholders in particular, it makes sense to create management and authority structures that, because they provide unified command and facilitate autonomous decision making, enable companies to act (and react) quickly and decisively to market opportunities. This approach leads, for instance, to the combination of the roles of chair and chief executive officer (CEO), and for audit committees to be either non-existent or lightweight. Resistance to the modern corporate governance movement today tends to be based on this theory.

The agency theory of corporate governance, on the other hand, sees shareholders as the principals and management as their agents. Agents will, however, act with rational self-interest: as employee directors of a company, they will tend to maximize their monetary compensation, job stability and other perks, and do no more than seek to appease shareholders. They cannot, in other words, be expected to act in the interests of the shareholders. They need, instead, to be monitored and controlled to ensure that the principals' best interests are served. This theory is the basis for most of today's corporate governance activity. Jenson and Meckling (1976) define corporate management as agents of the firm's owners, who are termed the principals. The former are authorized not only to act on behalf of the latter, but also in their best interest. According to Ang, Rebel and Lin (2000), the empirical observations of agency theory reveal that management might act irresponsibly, or have different objectives. These may be sub-optimal relative to shareholders wealth maximization, particularly if management behavior is not monitored, or they receive inappropriate incentives. In agency theory, a divergence in the interests of managers and shareholders causes managers to take actions that are costly to shareholders.

Hill (2008) states that to counteract corporate mis-governance a system is required whereby firms are monitored and controlled. Now termed "corporate governance," it should embrace the relationships between the ordinary shareholders, Board of Directors and senior management, including the Chief Executive Officer (CEO). In large public companies where goal congruence is a particular problem (e.g. Enron and the recent bank crisis in Nigeria) the Board of Directors (who are elected by the shareholders) and operate at the interface between shareholders and management is widely regarded as the key to effective corporate governance. In our ideal world, they should not only determine ethical company policies but should also act as a constraint or any managerial actions that might conflict with shareholders interests.

The market theory of corporate governance holds that it doesn't really matter whether managers see themselves as stewards or agents, because shareholders will simply sell in the market the stocks and shares of those companies whose directors 
are not generating adequate returns for their investment. To the extent that this theory was genuinely held, it was fatally undermined by the corporate scandals at the turn of the $21^{\text {st }}$ century: shareholders in Enron (including many of its employees) were unable to sell their shares (many of which were held in pension plans) once it became clear that the company's governance was wholly inadequate.

\section{Corporate Governance in the Nigerian Banking Industry}

The banking crisis of 2009 is largely traceable to poor corporate governance in the Nigerian banking industry. The primary goal of corporate governance is to enhance the value of a company through ethical behavior, espousing a policy of openness and fairness and ensuring informed decision making throughout the company. Unfortunately, the center of corporate ethics - the board of directors - in certain cases became a magnet for unethical practices. Blinded by the glare of a rapidly growing stock market, pressured by stockholders for ever-increasing returns, and led by executives seeking to maximize bonuses based on stock performance, certain boards of directors and audit committees failed to constrain "creative" accounting to keep up their earnings numbers. It must have seemed to some directors that the investing public really did not care about issues such as executive compensation, as long as they made their double-digit returns. The ratio of executive pay to that of the average worker ballooned to 600 to 1 in 2000, from 100 to 1 in 1990. Closed, entrenched boards magnified the problem as directors rewarded themselves for "quality" performance until, finally, the bubble burst. Poor corporate governance in the banking industry gave rise to earnings management which adversely affected the industry. Schipper (1989) argues that excessive earnings management will distort information content of earnings. Healy and Wahlen (1996, p.6) state that earnings management occurs when managers use judgment in financial reporting and in structuring transactions to alter financial reports to either mislead some stakeholders about the underlying economic performance of the company or to influence contractual outcomes that depend upon reported accounting numbers. Managers also adopt the use of specific accruals in managing earnings (Mills \& Newberry, 2001). The specific accrual approach focuses on an industry's nature in which a single accrual is sizeable enough to be used in managing earnings. For example, the loan loss provision is a specific accrual that calls for substantial judgment in the banking industry. Sanusi (2012) and Brownbridge (1996) among others have provided anecdotal evidences of earnings manipulation in the Nigerian banking sector as a result of poor corporate governance.

There was gross insider abuse in the industry. Garuba (2011) states that insider abuse includes any facility extended by a bank to a shareholder, board member, management staff, relations or related companies. It also includes failure to disclose the interest of the borrower or customer in his business dealings with the 
financial institution, diverting assets and income for the insiders own use; misuse of position by approving questionable transactions for relatives, friends and business associates; abuse of expense accounts; acceptance of bribes and gratification; and other questionable dealings related to their positions at the institutions. Indulging in such abuses in the banking industry usually undermines the laid down guidelines and regulations, resulting in non-performing loans and ultimately lead to bank failure. This led to poor corporate governance in the banking industry because there was no transparency in doing banking business. The banks failed to make full disclosure and adequate provisions. Figure 2 below extracted from the Central Bank of Nigeria 2008 Annual Report gave an insight into what transpired then in the industry.

Fig- 2 Ratio of non-performing credit to total credit.

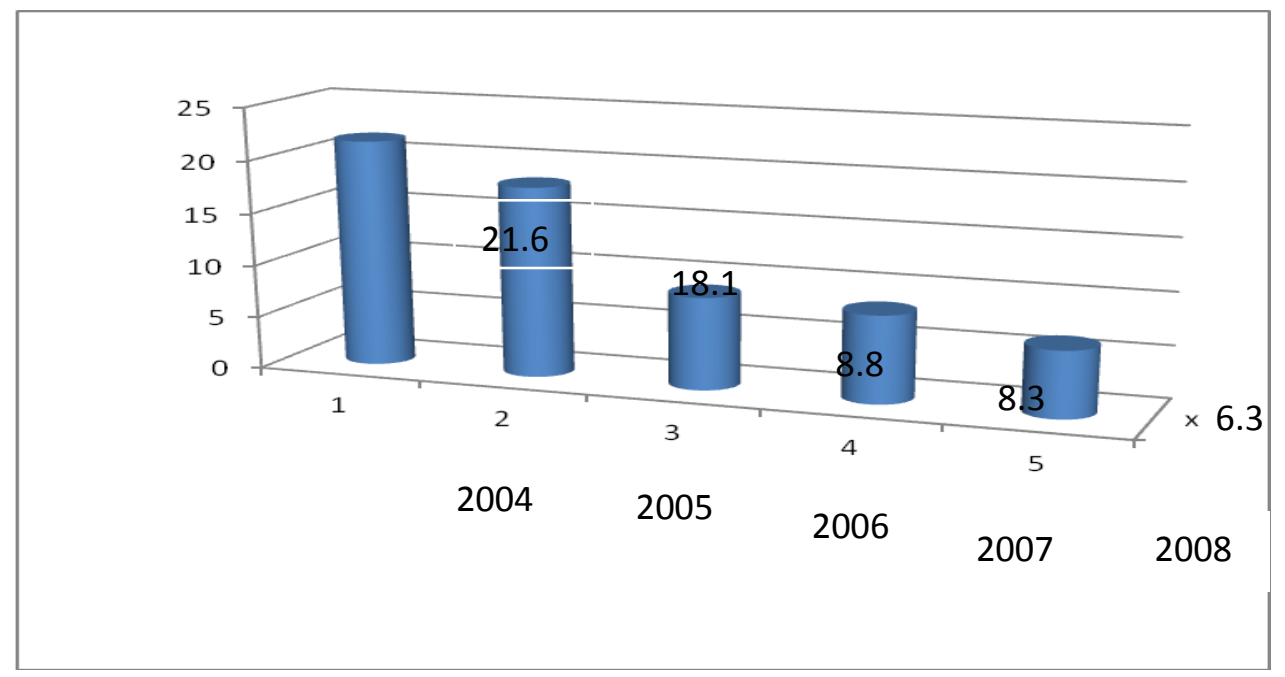

\section{SOURCE: CBN 2008 ANNUAL REPORT}

Non-performing credits are facilities that are past due for 90 days or more. Based on the 1990

Prudential guidelines, non-performing credits are categorized into three: Substandard (past due for 90 days or more but below 180 days), Doubtful (past due for 180 days or more but below 360 days) and Loss (past due for 360 days or more). Banks are expected to make specific provisions as follows: sub-standard $-10 \%$ of outstanding principal amount, doubtful-50\% of outstanding principal amount and loss 
$-100 \%$ of outstanding principal amount. While a general provision of at least $1 \%$ should be made for all performing credits because of the recognition of the fact that even performing facilities harbour some risk of loss no matter how small.

From fig 2 above one would have observed that the asset quality of banks as measured by the ratio of non-performing loans to industry total loans improved in 2008 at 6.3 percent, reflecting a $2 \%$ points decline from the preceding year's level. This portrayed a good asset quality for the banking industry during the period under review. But the question of "full disclosure" readily comes to mind. On August 14, 2009, the immediate past Governor of the Central Bank of Nigeria (CBN), Mallam Sanusi Lamido Sanusi made it known to the public when he sacked five managing directors/directors that the five troubled banks were guilty of lack of full disclosure and adequate provisioning among others, based on the report of the examination conducted by a joint team of CBN and NDIC Officials. In fact, he attributed the excessively high level of non-performing loans in the said banks to "poor corporate governance practices, lax credit administration processes and absence or nonadherence to the banks credit risk management practices". According to him, "the huge provisioning requirements have led to significant capital impairment. Consequently all the banks are undercapitalized for the current levels of operations and are required to increase their provisions for loans losses, which impacted negatively on their capital." When the banks were compelled by the CBN to make adequate provisions for the non-performing loans, virtually all the banks made huge losses. According to Ighomwenghion (2009), the banks' made huge losses after making a provision of N2.216 trillion. It again showed that most of the banks were declaring 'paper profits' because after provisioning at the instance of the CBN, most of the banks that were declaring jumbo profits over the years, declared losses.

The scandals of the last few years came as a shock not just because of the enormity of global financial failures, but because of the discovery that questionable accounting practice was far more insidious and widespread than previously envisioned. A definite link between these accounting failures and poor corporate governance is beginning to emerge. Hence the quest for good corporate governance has become the dominant theme in global economic discourse.

\section{Issues and Challenges of Corporate Governance}

The corporate collapses, business failures and fraudulent financial reporting scandals of the late 1990s and early 2000s led to a very turbulent time and resulted in a credibility crisis for the Auditing profession. The period 2000 through 2006 was a very turbulent time for the auditing profession, a period that witnessed numerous scandals and their aftermath (Enron, WorldCom [USA], Parmalat [Italy], Lever Brothers, Union Dicon Salt, Cadbury [Nigeria]), strident calls for changes in the way that auditors practise their profession, and regulatory initiatives that significantly 
change the way the profession is governed. The period 2009 and 2010 was also a trying period for auditors in Nigeria because the credibility of their corporate reports for banks was at stake. According to Anao (2010), it is believed that if accountants and auditors maintained the high ethical conduct expected of them many of the recent corporate scandals would not have been possible.

These scandals prompted countries like the United States to impose additional checks and balances via the audit process, government oversight, and the ever vigilant "plaintiff's attorney". These checks are to serve as a vital role in providing additional safeguards against the errant accountant. The additional checks and adherence to professional ethical code by auditors/accountants would help to restore public trust in corporate reporting.

The interests of investors and other stakeholders are usually protected by a three-tier security system. At the top level is the company's governance code which is directed toward enforcing company policies, achieving company objectives, monitoring company performance, and ensuring adequate disclosure of the company's activities. At the other end is the reporting system regulated by public and private institutions such as the Securities and Exchange Commission (SEC), the Public Company Accounting Oversight Board (PCAOB), and Financial Accounting Standard Board (FASB), which subject public companies to accounting and disclosure standards, and their auditors to audit, independence, ethical, and quality control standards. Linking the two extremes is a company's system of internal control, which provides reasonable assurance on the effectiveness and efficiency of operations, the reliability of financial reporting, and compliance with applicable laws and regulations. This system, however, seems to have been inadequate in many companies including banks.

There is also lack of a well developed and implemented policy of corporate governance in most organizations. The CBN in trying to address this issue has overhauled the corporate governance for banks of 2006. It also changed the tenure of banks' auditors to a maximum period of five years, managing directors' tenures fixed at a maximum of ten years and all banks now maintain the same 'end of financial year' of 31st December.

Another critical issue is lack of honesty and transparency in reporting. The financial reporting standards in the United States are the most highly specified in the world. But falling stock markets, corporate failures, dubious accounting practices, abuses of corporate power and criminal investigations indicate that the system is under stress. Some corporations have grown dramatically through acquisitions funded by inflated stock prices and promises of an even brighter future. This was what most Nigerian banks did by fraudulently over-pricing their shares on the stock market. In other banks, it seems as if the checks and balances that should protect 
shareholder interests were pushed aside, driven by pursuit of the bottom line. It has traditionally been an auditor's responsibility to express an opinion on whether financial statements are presented according to generally accepted accounting principles (GAAP). Contrary to the expectations of many in the public, the auditor does not have an absolute duty to uncover fraud, although Statement of Auditing Standards 99 prescribes steps for auditors to take in order to ensure that they have planned and implemented their audits in a way that responsibly addresses fraud considerations. It therefore, shows that there is expectation gap between the auditors and the public.

There is also the issue of an ineffective and inefficient system of internal control. Garuba (2008) states that internal controls are those procedures, policies, rules and regulations established by management within an entity in order to increase the probability of the achievement of the entity's objectives. It is the responsibility of the management to set up adequate controls to ensure that the business is conducted in an orderly and efficient manner that the assets of the entity are safeguarded, that management policies are complied with and that records are complete and reliable. A good system of internal control will usually help a company achieve its objectives of profitability and minimize loss of resources. Internal control cannot, however, change an inherently weak management system or provide absolute assurance as to the reliability of financial reporting. Companies are now facing increasing levels of legal, regulatory, and economic reporting requirements, because of the SarbanesOxley Act of 2002 (SOA). Companies are spending millions of naira and dollars examining their existing systems, and adopting or improving their governance and internal controls to meet the standards set by SOA sections 403 and 404. In today's rapidly changing business landscape, it is now necessary for accountants and companies to step away from the traditional approach that emphasized compliance with GAAP, and to focus on the study and investigation of the traits underlying corporate behavior and management. This could be the key to preventing future corporate failures, and to guaranteeing the two important qualities of corporate reporting: transparency and honesty.

Therefore, to address these challenges, stakeholders should ensure that public companies including banks do not violate the relevant statutes/guidelines, specifically prescribed by a regulatory authority, and should identify the applicability of any such conditions separately. Garuba (2010) posits that banks should adhere to the code of corporate governance which was introduced to ensure soundness and transparency in the conduct of banking business in Nigeria. They should also obtain and review the quarterly compliance reports submitted by the company to the stock exchanges in the prescribed format and note down any non-compliance. Finally, the government must provide the enabling environment to enable business organizations operate in the economy. Donwa and Garuba (2011) stressed that apart from providing the enabling 
environment, government should display transparency in governance. Sullivan (2001) states that how often it has been said, the government should get out of the way and let the market function. Of course, the idea is a myth. Government is absolutely essential in setting up the framework of a market economy; without rules and structures of a binding nature, anarchy results.

\section{Conclusion}

It has been established in this paper that poor corporate governance has been the root of recent failures rocking the global financial sector. Therefore, to contain these emerging realities and ensure investors' confidence in corporate reporting, the issue of corporate governance has to be addressed. All stakeholders, especially the government have a role to play by ensuring that the necessary institutions and environment are put in place. The shareholders must rise to the increasing demanding role of moderating errant chief executive officers (CEOs) and the board of directors.

\section{Recommendations}

We do hope that if management and relevant policy formulators apply the following recommendations proffered, it will go a long way in addressing poor corporate governance in the Nigerian banking industry:

1. There should be zero tolerance for infraction of the corporate governance of the banking industry;

2. The regulatory bodies must be alive to their responsibilities by ensuring that they carry out checks and monitoring of the banks;

3. The Nigerian government should establish an oversight body like what is obtainable in the US to act as a check on the performance of the Auditors;

4. The certification of financial reports by the Chief Executive Officer and Chief Financial Officer of banks is commendable. It should be sustained and extended to non-financial institutions because it helps to credibility to the financial reports;

5. The Central Bank of Nigeria should put in place a good and a reliable management information system (MIS); not only to facilitate the day-to-day of its operation but to link and monitor banks' transactions;

6. The shareholders' must be alive to their responsibilities by being active at the Annual General Meeting, and asking questions where necessary;

7. The judiciary should review the judicial process to allow for quick dispensation of justice; 
8. Institutions such as the Economic and Financial Crime Commission (EFCC) and Independent and Corrupt Practices Commission (ICPC) should be strengthened to enable them discharge their duties effectively and efficiently and

9. Government should create the necessary and conducive environment for good corporate governance.

\section{References}

Ang, J. S., Rebel, A.C. \& Lin, J.W. (2000). Agency Cost and Ownership Structure. Journal of Finance. 55(2): 202-210.

Akintoye, I.R. (2010). Corporate Governance and Reporting. Being paper presented at ICAN Interactive Session for Accountants in Education. Lagos, 8th March, 2010.

Anao, A.R. (2010). Educating the Accountant to meet prevailing global challenges. Being paper presented at ICAN Interactive Session for Accountants in Education. Lagos, 8th March.

Brownbridge, M. (1996). The Impact of Public Policy on the Banking System in Nigeria. Zaria, Nigeria: Institute of Development Studies.

Central Bank of Nigeria (2008). Annual Report and Financial Statements: Abuja.

Donwa, P. \& Garuba, A. O. (2011). Prevailing Global Challenges and the Accounting Profession. Franklin Business \& Law. 2011(2): 1-12

Garuba, A.O. (2008). Fundamentals of Banking, Vol. 1. Benin City: Ambik Press Ltd.

Garuba, A.O. (2010). Credit Risk Management in the Nigerian Banking Industry. JORIND, $8(2 b), 372-381$.

Garuba, A.O. (2011). Credit Administration in the Nigerian Banking Industry. Germany: Lambert Academic Publishing.

Healy, P. M., \& Wahlen, J. (1999). A Review of the Earnings Management Literature and its Implications for Standard Setting. Accounting Horizons, 13(4), 365384.

Hill, R. A.(2008). Strategic Financial Management. Author Finance \& Ventus Publishing ApS. Download Free Textbooks at BOOKBOON.Com.

Ighomwenghian, K. (2009). 2009 in Retrospect: When Sanusi's Tsunami Caught Nigerian Economy Unawares. Daily Independent, December 30th, p.11. 
Jensen, M. (1993). The Modern Industrial Revolution, Exit and the Failure of Internal Control Systems. Journal of Finance, 48 (3), 831-880.

Jenson, M.C. \& Meckling, W.H. (1976). Theory of the Firm: Managerial Behaviour, Agency Cost and Ownership Structure. Journal of Financial Economics, 48, 35- 54.

Owojori, A.D. (2010). Corporate Governance and Disclosure: The impact of Corruption and Unaccountability on National Development. Being a paper presented at ICAN Interactive Session for Accountants in Education. Lagos, 8th March.

Sanusi, L. S. (2012). Banking Reforms and its Impact on Nigerian Economy. Being a lecture delivered at the University of Warwick's Economic Summit, UK 17th February. Retrieved from: www.cenbank.org.

Schipper, K. (1989). Commentary on Earnings Management. Accounting Horizons 3(4): 91-102.

Sullivan, J. (2001). Corporate Governance: Transparency between Government and Business. Business Times, 16th April, p8. 